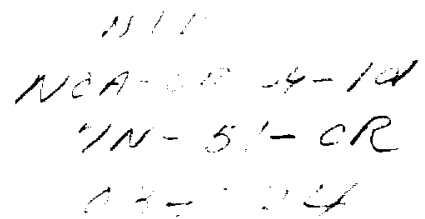

\title{
Effect of the Angiotensin I Converting Enzyme Inhibitor, MK-421, on Experimentally Induced Drinking
}

\author{
MELVIN J. FREGLY, DENNIS C. FATER and JOHN E. GREENLEAF' \\ Department of Physiology. University of Florida
}

\begin{abstract}
MK-421, the ethyl ester maleate salt of N-[S]-1-(ethoxycarbonyl)-3-phenyl-propylAla-L-Pro, is an angiotensin I converting enzyme inhibitor. An initial objective was to determine whether MK-421, administered at $0,2 \cdot 5,5 \cdot 0,10 \cdot 0,20 \cdot 0$ and $40 \cdot 0 \mathrm{mg} / \mathrm{kg}$, ip to 96 female rats $15 \mathrm{~min}$ prior 10 administration of the $\beta$-adrenergic agonist, isoproterenol $(25 \mu \mathrm{g} / \mathrm{kg}$, ip), would inhibit the drinking induced by isoproterenol during $2 \mathrm{~h}$ after its administration. The water intake induced by isoproterenol was inhibited significantly by $2.5 \mathrm{mg}$ MK $-421 / \mathrm{kg}$. When a similar experiment was performed using angiotensin I (AI) $(200 \mu \mathrm{g} / \mathrm{kg}, \mathrm{ip})$ as the dipsogenic agent, MK-421 $(5 \mathrm{mg} / \mathrm{kg}$, ip), administered $15 \mathrm{~min}$ prior to AI, inhibited significantly both the dipsogenic and the diuretic effect of AI. However, administration of angiotensin II (AII, $200 \mu \mathrm{g} / \mathrm{kg}$, ip) $15 \mathrm{~min}$ after MK-421 $(5 \mathrm{mg} / \mathrm{kg}$ ) was accompanied by a water intake that did not differ from AII alone. The drink induced by ip administration of $1.0 \mathrm{M} \mathrm{NaCl}$ solution $(1 \%$, of body wt, ip) was not inhibited by administration of MK$421(5 \mathrm{mg} / \mathrm{kg}) 15 \mathrm{~min}$ prior to allowing access to water while the drink induced by a $24 \mathrm{~h}$ dehydration was partially inhibited. Thus, the drinks induced by administration of either isoproterenol or AI are dependent on formation of AII. That induced by dehydration is partially dependent, while that induced by hypertonic saline is independent of the formation of AII.
\end{abstract}

MK -421 is a compound that inhibits the conversion of angiotensin I to angiotensin II (Gross, Sweet, Ulm, Backhind, Morris, Weitz, Bohn, Wenger, Vassel, \& Stone, 1981). Since the drinking induced in rats by acute administration of the $\beta$-adrenergic agonist, isoproterenol, is most likely induced by way of the renin-angiotensin system (Fitzsimons, 1979), an initial objective of this study was to determine whcther isoproterenol-induced drinking could be inhibited by administration of MK-421. Additionally, the effect of MK-421 on the dipsogenic responses to acute administration of angiotensin I and II were measured. A final objective was to determine whether administration of MK-42I affected the drinking responses of rats to an intraperitoneal load of hypertonic sodium chloride solution as well as to a 24 -h period of dehydration.

\footnotetext{
${ }^{1}$ Present address: Biomedical Research Division, NASA-Ames Research Center, Moflett Field. (CA.

${ }^{2}$ Supported by Contract NCA-OR204-101 from the National Aeronautics and Space Administration. Moffett Field, CA, U.S.A.

${ }^{3}$ We thank Mr Thomas Connor and Mr Howard Clark for technical assistance and Mrs Chatotte Fdelstein for the graphic illustrations.

${ }^{4}$ Request for reprints should be addresssd to Dr Melvin J. F regly, Department of Physiology. Box 1.274. Iniversity of Floridit. (ollege of Medicine, (Gainewille. FI 3261). U.S.A. 


\section{MiTHODS}

Experiment 1: Effect of Varying Doses of MK-421 on Isoproterenol-induced Drinking

Ninety-six female rats of the Blue Spruce Farms (Sprague-Dawley) strain weighing 250-290 $\mathrm{g}$ were placed in individual metabolic cages. MK $-421,{ }^{1}$ dissolved in saline, was administered intraperitoneally in doses of $0,2 \cdot 5,5 \cdot 0,10 \cdot 0,20 \cdot 0$, and $40 \cdot 0 \mathrm{mg} / \mathrm{kg}$ body wt $15 \mathrm{~min}$ prior to subcutaneous injection of $25 \mu \mathrm{g}$ isoproterenol $/ \mathrm{kg}$ body wt. Immediately after isoproterenol was injected, each rat was given a preweighed water bottle containing tap water $(26 \mathrm{C})$. Water intake was measured hourly for $2 \mathrm{~h}$. Fluid containers consisted of infant nursing bottles with cast bronze fountains as described by Lazarow (1954).

The effect of treatment on mean water intakes of the six groups was assessed by a one-way analysis of variance (Goldstein, 1964). Differences between groups were compared by means of a $t$-test using the pooled variance from the analysis of variance (Huntsberger, 1961). Significance was set at the 95 percent confidence limit.

\section{Experiment 2: Effect of Estrus Cycle on Water Intake Induced by Isoproterenol}

Since the phase of the estrus cycle has been shown to influence the drinking response to low doses of isoproterenol in rats (Findlay, Fitzsimons \& Kucharczyk, 1979), 50 female rats of the Blue Spruce Farms (Sprague-Dawley) strain weighing 250-300 g were used to test the effect of phases of the estrus cycle on the drinking response to a moderate dose of isoproterenol. The rats were maintained in cages that were designed to assess their locomotor activity (Fregly \& Black, 1964). Female rats characteristically increase their locomotor activity at estrus (Wang. 1923). After the activity cycle was established ( 12.15 days), vaginal smears were also taken daily in the late afternoon and the smears were examined microscopically after staining with $0.25 \%$ methylene blue. The criteria for assessment of the vaginal cytology were essentially those of Long \& Evans (1922).

Once weekly for three weeks, rats whose status in the estrus cycle had been characterized both by their running activity and vaginal smears were used to measure their drinking responses to isoproterenol ( $50 \mu \mathrm{g} / \mathrm{kg}$ body wt, s.c.). In each study, about half of each group received isotonic saline $(1 \mathrm{ml} / \mathrm{kg}$, s.c.). The drinking test was conducted in the same fashion as that deseribed in Experiment 1.

\section{Experiment 3: Effect of MK-421 on the Responses of Blood Pressure and Heart Rate to Administrution of Isoproterenol}

Ten female rats weighing $220-260 \mathrm{~g}$ were anesthetized with pentobarbital $(40 \mathrm{mg} / \mathrm{kg})$ and the left carotid artery cannulated with PE 50 tubing. The cannula was tunneled beneath the skin and emerged at the back of the head. Each cannula was filled with heparinized saline $(300 \mathrm{U} / \mathrm{ml})$ and plugged with a $22 \mathrm{G}$ stainless steel stylet. The rats were caged individually. Two days after cannulation, the rats were transported in their cages to an adjoining quiet room. The implanted cannula was attached to a pressure transducer (Statham P23DB) coupled to a Grass polygraph. The rats were unanesthetized and remained in their cages for a 1-h control period. Half of the rats were then administered $\mathrm{MK}-421(5 \mathrm{mg} / \mathrm{kg}$, ip) while the remaining rats received isotonic saline $(1 \mathrm{ml} / \mathrm{kg}$, ip). One-half hour later, all rats received isoproterenol

'MK-421 was generously provided by Dr E. H. Blaine, Director, Renal Pharmacology, Merck Institute for Therapeutic Research, West Point, PA 19486. 
( $25 \mu \mathrm{g} / \mathrm{kg}$, s.c.). Both blood pressure and heart rate were measured at $5 \mathrm{~min}$ intervals for the first half-hour and at $10 \mathrm{~min}$ thereafter for the remainder of the $120 \mathrm{~min}$ experiment.

Experiment 4: Effect of $M K-421$ on Angiotensin I-induced Drinking

To assess the effect of MK $-42 \mathrm{I}$ on angiotensin I-induced drinking, four groups of six rats each were treated as follows: Group 1 received the saline vehicle, Group 2 received angiotensin I (United States Biochemical Corp., Cleveland, Ohio) $(200 \mu \mathrm{g} / \mathrm{kg}$ body wt, s.c.); Group 3 received MK -421 (5 $\mathrm{mg} / \mathrm{kg}$ body wt, ip), and Group 4 received both angiotensin I and MK-421. MK-421 was administered to Groups 3 and 415 min prior to administration of angiotensin $I$. Groups 1 and 2 received an equal volume of saline. Groups 2 and 4 received angiotensin I 15 min later, while Groups 1 and 3 received an equal volume of saline. Immediately after the last injection, the rats were placed in individual metabolic cages and given a preweighed water bottle. Collection of urine was begun at this time. Water intakes and urine outputs were measured 1 and $2 \mathrm{~h} \mathrm{later}$. Statistical analysis was performed by means of a two-way analysis of variance (Snedecor and Cochran, 1956).

\section{Experiment 5: Effect of $\mathrm{MK}-421$ on Angiotensin II-induced Drinking}

As in experiment 2, four groups composed of six rats each were studied: Group 1 received the vehicle; Group 2 was injected with angiotensin II (200 $\mu \mathrm{g} / \mathrm{kg}$ body wt s.c.); Group 3 was injected with $\mathrm{MK}-421(5 \mathrm{mg} / \mathrm{kg}$ body wt ip) and Group 4 received angiotensin II and MK-421. MK-421 was administered to Groups 3 and 415 min prior to treatment with Angiotensin II. The remaining two groups received an equal volume of saline. Groups 2 and 4 received angiotensin II 15 min later, while Groups 1 and 3 were injected with an equal volume of saline. The remainder of the protocol of this experiment was identical to that of experiment 2.

Experiment 6: Effect of MK-421 on Drinking Induced by Intraperitoneal Injection of Hypertonic Sodium Chloride Solution

Twenty-four female rats were divided equally into four groups. Group 1 was untreated; Group 2 received MK $-421(5 \mathrm{mg} / \mathrm{kg}$ body wt); Group 3 received $1 \%$ of its body weight of a $1.0 \mathrm{M} \mathrm{NaCl}$ solution intraperitoneally, and Group 4 received MK-421 followed by an intraperitoneal load of hypertonic $\mathrm{NaCl}$ solution. MK-421 was administered $15 \mathrm{~min}$ prior to loading with $\mathrm{NaCl}$ solution. The groups that did not receive MK-421 received an equal volume of the vehicle. Immediately after injection of the $\mathrm{NaCl}$ solution, the rats were placed in individual metabolic cages and each rat was given a preweighed water bottle. Water intakes were measured 1 and $2 \mathrm{~h}$ later.

\section{Experiment 7: Effect of $M K-421$ on Dehydration-induced Drinking}

Four groups of six rats each were used in this experiment: Group 1 was a waterreplete control group; Group 2 was also water-replete but received MK-421 (5 mg kg, body wt, ip); Group 3 had been deprived of water for $24 \mathrm{~h}$, and Group 4 was both dehydrated and injected with MK-421 (5 mg/kg body wt, ip). MK -421 was administered $15 \mathrm{~min}$ prior to allowing rats access to water. The remaining rats received an equal volume of saline at this time. Each animal was placed in an individual metabolic cage $15 \mathrm{~min}$ later and given a preweighed water bottle. Water intakes were measured at 1 and $2 \mathrm{~h}$ later.

Statistical analyses of Experiments 5,6 and 7 were performed as described in Experiment 4. 


\section{RESULTS}

\section{Experiment 1}

Each dose of MK-421 reduced significantly the drinking response characteristically observed after administration of isoproterenol (Figure 1). The reduction in water intake during both hours was roughly a linear function of the dose of MK-421 administered. There appears to be little question that MK-421 is capable of inhibiting the drinking response to isoproterenol and that it was effective for at least the $2 \mathrm{~h}$ of this study.

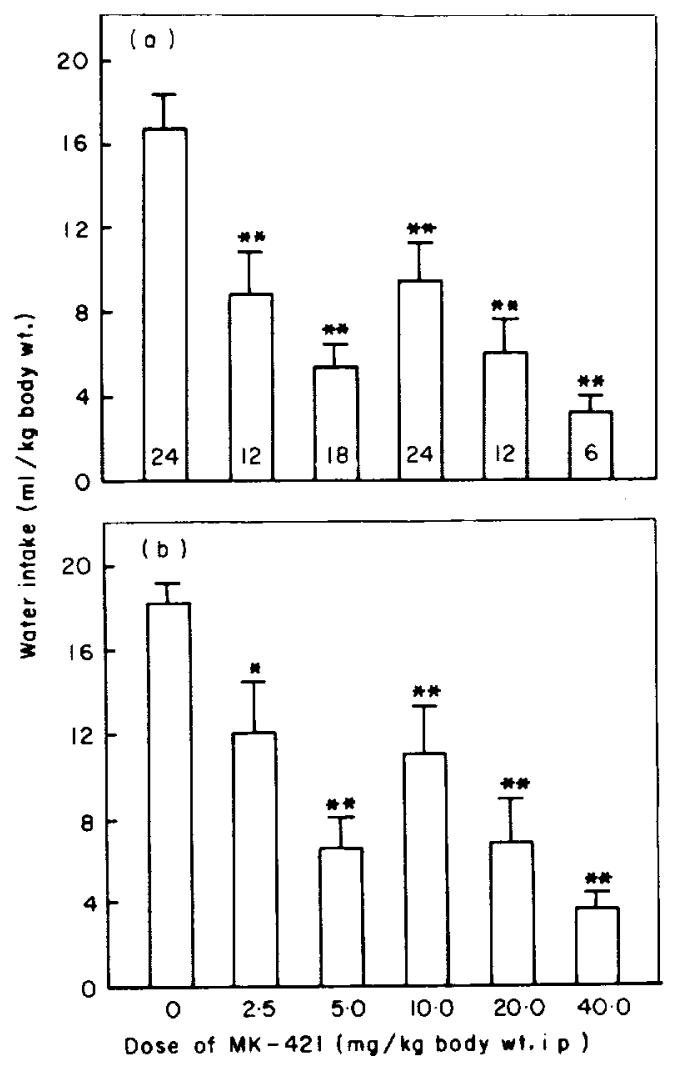

Figurf 1. The dose-response relationship between dose of MK-421 administered and accumulative water intake during the first $h(a)$, and first $2 h(b)$ following administration of $25 \mu \mathrm{g}$ isoproterenol $/ \mathrm{kg} \mathrm{s.c.} \mathrm{is} \mathrm{shown.} \mathrm{Isoproterenol} \mathrm{was} \mathrm{administered} 15 \mathrm{~min}$ after administration of MK-421. The numbers in each bar represent the number of animals tested at each dose of MK421 . One standard error is set off at each mean. ${ }^{*} p<0 \cdot 05 ;{ }^{* *} p<0 \cdot 01$ compared to control group (0 dose).

\section{Experiment 2}

Ingestion of water in response to administration of isoproterenol at $50 \mu \mathrm{g} / \mathrm{kg}$ was not affected significantly by the phases of the estrus cycle as was observed by Findlay, Fitzsimons, \& Kucharczyk (1979) for much lower doses (4 $\mu \mathrm{g} / \mathrm{kg})$ (Figure 2). Water intake in response to administration of isotonic saline was also unalfected by the phases of the estrus cycle (Figure 2). It is apparent from this study that the effect of phases of the 


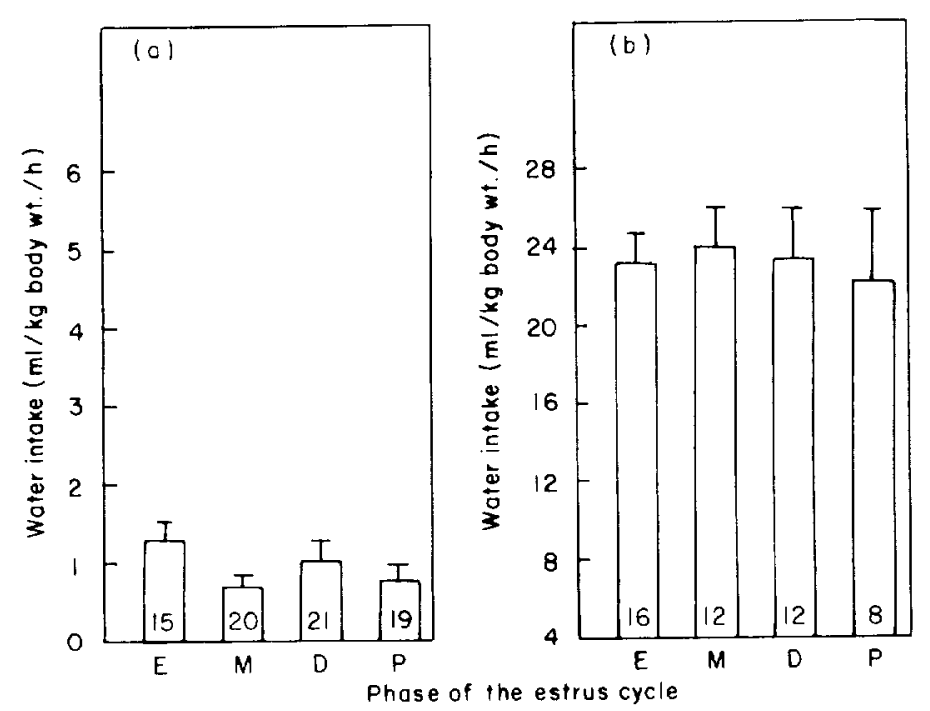

Figulr: 2. Mean water intake of rats administered either siline $(1 \mathrm{ml} / \mathrm{kg}$ body wt, s.c.)(a) or isoproterenol ( $50 \mu \mathrm{g} / \mathrm{kg}$ body w1, s.c.) (b) during the various phases of the estrus cycle of the rat. The initials of the various phases are listed under the bars and include: $E$ (estrus), $M$ (metestrus), $\mathrm{D}$ (diestrus) and $\mathrm{P}$ (proestrus). The numbers in each bar represent the number of rats tested. One standard error is set off at each mean.

estrus cycle on water intake of rats is observed most readily with low doses of isoproterenol and is masked by higher doses.

Experiment 3

Administration of MK-421 $(5 \mathrm{mg} / \mathrm{kg})$ had no significant effect on the responses of either mean blood pressure or heart rate to administration of isoproterenol (Figure 3). When the MK-421 treated group was compared to controls, the change in mean blood pressure failed to differ during the first $40 \mathrm{~min}$. Thereafter, the blood pressure of the MK -421 treated group returned to pretreatment level, in contrast to the control group whose mean blood pressure remained depressed throughout the study.

Mean change in heart rate was similar for both groups throughout the study. Heart rate increased above pretreatment level within 1 min of the subcutaneous injection of isoproterenol; reached maximal levels within approximately $30 \mathrm{~min}$, and returned to pretreatment level within $90 \mathrm{~min}$ after treatment.

\section{Experiment 4}

MK-421 (5 mg/kg body wt, ip) prevented both the dipsogenic and diuretic responses that characteristically accompany administration of angiotensin I to rats (Fregly, 1980) (Figure $4 \mathrm{a}$ and b). However. MK-421 alone had no significant effect either on water intake [Figure 4 (a) and (b)] or urine out put [Figure 4 (c) and (d)] during the $2 \mathrm{~h}$ of the study.

\section{Experiment 5}

Administration of MK-421 in combination with angiotensin II had no effect on the drinking response normally elicited by administration of angiotensin II alone (Fregly, 


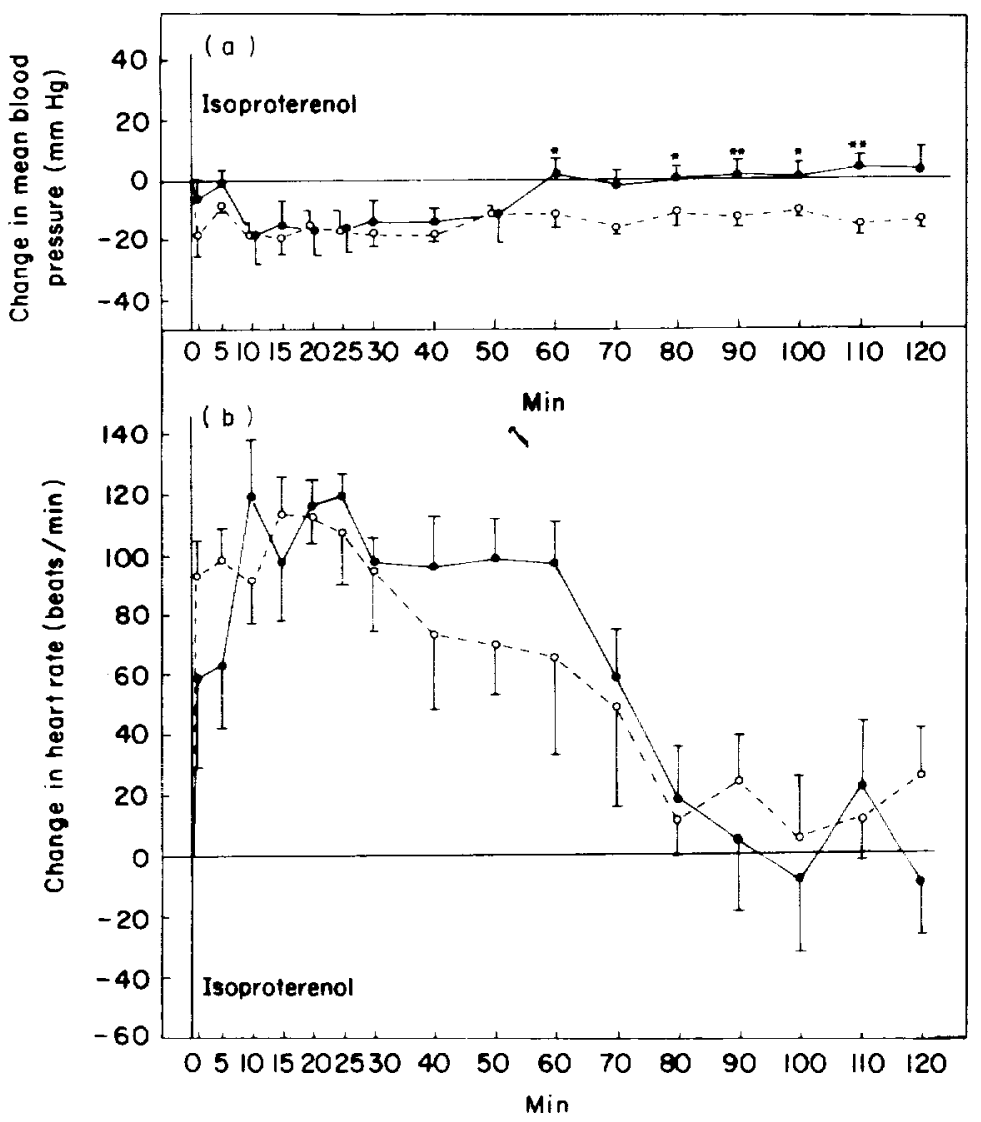

FIGURE 3. The changes in mean blood pressure (a) and mean heart rate (b) of conscious rats administered isoproterenol $(25 \mu \mathrm{g} / \mathrm{kg}$ body wt, s.c.) are shown. Half of the rats were pretreated with $\mathrm{MK}-421(5 \mathrm{mg} / \mathrm{kg}$, ip)(O); $30 \mathrm{~min}$ prior to administration of isoproterenol control (O). One standard error is set off at each mean. ${ }^{*} p<0.05 ;{ }^{* *} p<0.01$ compared to control group.

1980) (Figure 5). The rats receiving MK-421 plus angiotensin II drank virtually the same amount of water as those receiving only angiotensin II. Water intake in these two groups was significantly greater than that of either the control animals which received no drug or those administered MK-421 alone. Treatment with MK-421 alone had no effect on water intake beyond that of the control group.

\section{Experiment 6}

The water intake that characteristically accompanies intraperitoneal loading with hypertonic $\mathrm{NaCl}$ solution was not affected by prior administration of $\mathrm{MK}-421$ (Figure 6). No significant difference in drinking response was observed between the rats administered an intraperitoneal load of hypertonic saline and MK-421 and those that received only the hypertonic saline load. Both groups drank significantly more than either the control or the group that received MK-421 only. Water intakes of the latter two groups did not differ significantly from each other. 

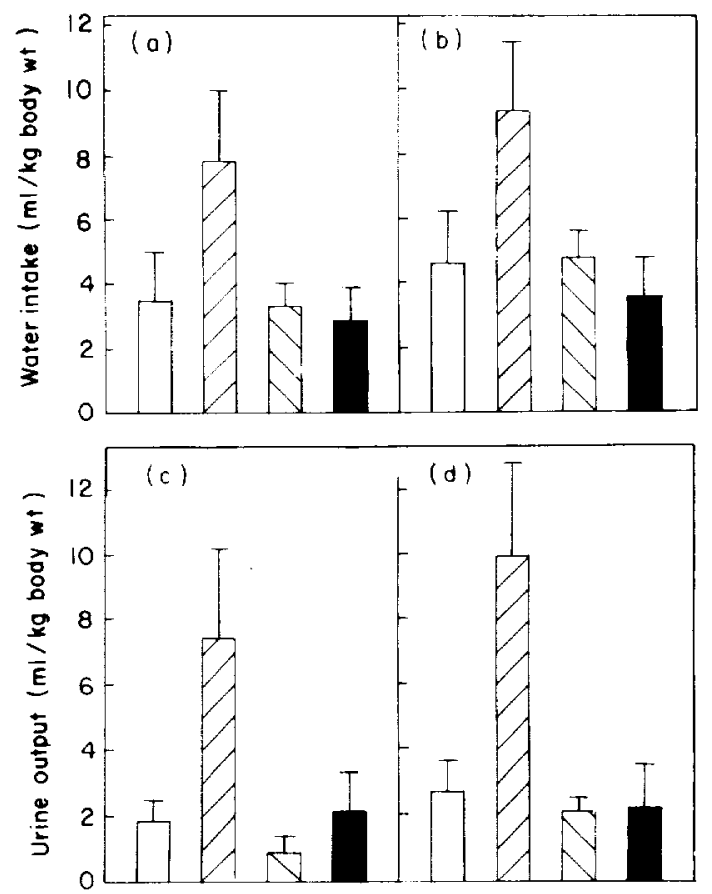

FigilRI 4. Accumulative water intakes (upper panels) and urine outputs (lower panels) during the first hour [(a) and (c), and first $2 \mathrm{~h}(\mathrm{~b})$ and (d)] following administration of angiotensin 1 $(\nabla)(200 \mu \mathrm{g} / \mathrm{kg}$ body wt, ip). MK $-421(\$)(5 \mathrm{mg} / \mathrm{kg}$ body wt, ip) and both drugs $(\square)$ are shown. control $(\square)$. Angiotensin I was administered $15 \mathrm{~min}$ after administration of MK-421. One standard error is set off at each mean.

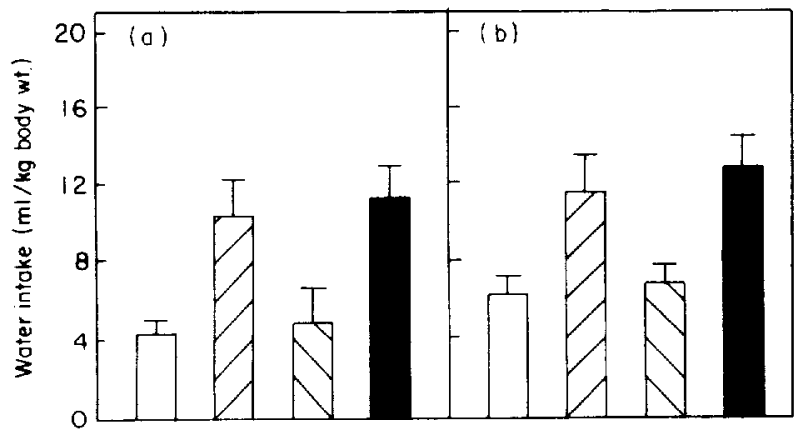

FIGil'RF 5. Accumulative water intakes during the first hour (a) and first $2 \mathrm{~h}$ (b) following

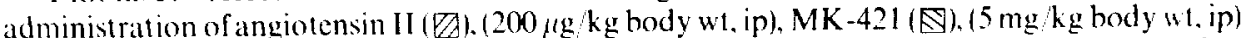
and both drugs $(\square)$ is shown, control $(\square)$ : Angiotensin II was administered 15 min after administration of MK-421. One standard error is set off at each mean. 


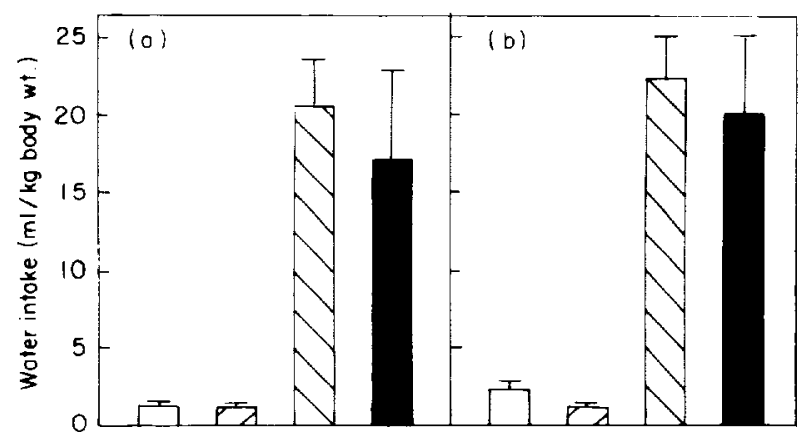

Fritirl 6. Accumulative water intakes during the first hour (a) and first $2 \mathrm{~h}$ (b) following administration of 1 per cent of body weight of $1 \mathrm{M} \mathrm{NaCl}$ solution, ip are shown. Hypertonic saline was administered $15 \mathrm{~min}$ after administration of $\mathrm{MK}-421(5 \mathrm{mg} / \mathrm{kg}$, ip). Control ( $\square)$; MK-421

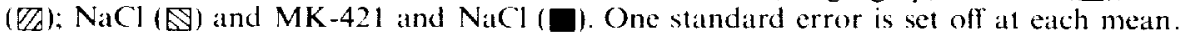

\section{Experiment 7}

Dehydration increased water intake significantly $(p<0.01)$ above that of the control group [Figure 7 (a) and (b)]. Administration of MK-421 to normally hydrated rats had no significant effect on water intake. When MK -421 was administered to dehydrated rats, water intake was attentuated significantly during both the first and second hours.

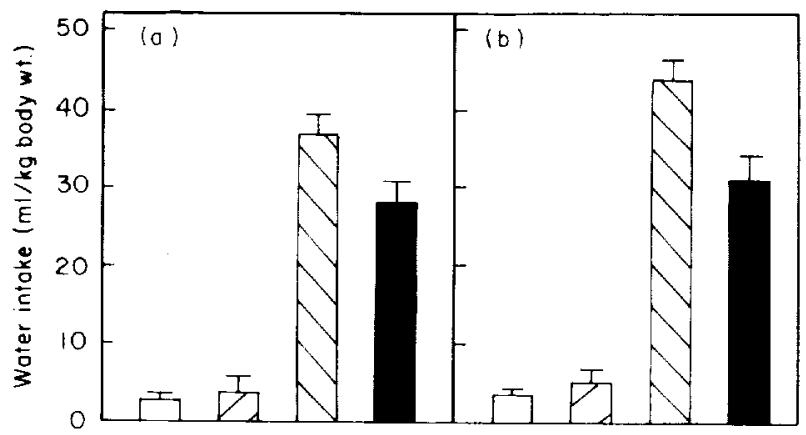

Ficic RI 7. Accumulative water intakes are shown during the first hour (a) and first $2 \mathrm{~h}$ (b) hours following return of water to rats that were dehydrated for $24 \mathrm{~h}$. MK $-421(5 \mathrm{mg} / \mathrm{kg}$, ip) was administered 15 min prior to allowing access to water. Control ( $\square$ ); MK-421 ( $/ 7$ ); dehydrated $(\Omega)$, and MK-421 and dehydrated $(\square)$. One standard error is set off at each mean.

\section{Discussion}

Inhibition of the angiotensin I converting enzyme by MK-421 attenuated significantly the drinking response accompanying acute administration of the $\beta$ adrenergic agonist, isoproterenol. The present results are the first to report this effect of MK-421 and to provide a dose-response curve for this particular relationship. Since the angiotensin I converting enzyme is also responsible for the inactivation of the peptide, bradykinin, the results suggest that either the failure to form angiotensin II. or the 
prolonged half-life of bradykinin, or both, may be responsible for the failure of isoproterenol to induce a dipsogenic response in rats treated with MK-421. The latter seems unlikely since only large doses of bradykinin, administered exogenously to rats in combination with an angiotensin I converting enzyme inhibitor, increased their drinking response (Fregly, Lockley, \& Simpson, 1981).

The results of Experiment 2 indicate that a moderate dose of isoproterenol can mask the effect of phases of the estrus cycle on water intake. In addition, the results of Experiment 3 suggest that MK-421 did not inhibit isoproterenol-induced drinking by preventing the decrease in blood pressure that characteristically accompanics its administration. Decreases in blood pressure during the first hour after administration of isoproterenol, when the major portion of the drinking response occurs, were similar for MK-421-1reated and control groups [Figure 3 (a)]. Further, MK-421 failed to atfect the characteristic increase in heart rate induced by isoproterenol [Figure $3(\mathrm{~b})]$. These results support the suggestion that inhibition of isoproterenol-induced drinking occurs as a result of blockade of the conversion of angiotensin I to angiotensin II by MK -421 .

Attenuation of the drinking response to isoproterenol was observed earlier with the compound, captopril, which is also an angiotensin converting enzyme inhibitor (Barney, Katovich, \& Fregly, 1980; Katovich, Barney, Fregly, \& McCaa, 1979). When the earlier results are compared with the present ones, a seven-fold greater activity of MK-421 over captopril in the inhibition of isoproterenol-induced drinking is apparent. This has not been reported previously.

Isoproterenol-induced drinking can be blocked by $\beta$-adrenergic antagonists ( $\mathrm{l}$ ehr. Mallow, \& Krukowski, 1967: Katovich \& Fregly, 1978). There is also experimental evidence suggesting that isoproterenol-induced drinking is mediated by the reninangiotensin system. This has been summarized recently by Fitzsimons (1979). Thus, Leenen \& McDonald (1974) and Scammell \& Fregly (1981) reported that administration of isoproterenol was accompanied by dose-dependent increases in plasma renin activity. Leenen \& McDonald (1974) also reported a dose-dependent water intake in their rats. That a reduction in blood pressure was not necessary for the release of renin to occur was shown by Weinberger. Aoi, \& Henry (1975) who reported that slices of kidney from rats released renin in citro when isoproterenol was added to the medium bathing the renal slices. Chiaraviglio (1979) reported that injection of saralasin, a competitive antagonist for angiotensin II receptors, into the third cerebral ventricles of rats blocked their drinking response to intraperitoneal administration of isoproterenol. These results may be interpreted to suggest that the drinking response to peripheral administration of isoproterenol requires: (a) the formation of angiotensin II peripherally; (b) the entrance of angiotensin II into the central nervous system, and (c) the binding of angiotensin II to receptors in the cerebral ventricles. However, there are still some unanswered questions regarding the involvement of the renin-angiotensin system in isoproterenol-induced drinking (Atkinson, Kaesermann, Lambelet, Peters, \& Peters-Haefeli, 1979; Blaine, Husut1, Rowland, Stricker, \& Zimmerman, 1979).

Administration of MK-421 to rats also attenuated their dipsogenic response to administered angiotensin I, but not to angiotensin II (Figures 4 and 5). This suggests that conversion of angiotensin I to angiotensin is important for the manifestation of a drinking response to administered angiotensin I. Similar results were also observed with captopril (Katovich, Barney, Fregly \& McCaa, 1979).

In contrast to its effect on the dipsogenic responses to isoproterenol and angiotensin I, MK-421, like captopril (Barney, Katovich \& Fregly, 1980), had no significant effect on the drinking response accompanying administration of hypertonic 
saline (Figure 6). This suggests that failure to form angiotensin II is not important for the drinking response to administration of hypertonic saline.

Administration of MK-421 attenuated the drinking response accompanying a 24-h period of dehydration; however, the drinking response was still significantly greater than that of hydrated rats treated with MK-421 (Figure 7). This suggests that dehydration-induced drinking is only partially dependent on the angiotensin II pathway for arousal of thirst and drinking (Greenleaf \& Fregly, 1982; Oatley, 1978).

Abdelaal, Mercer, \& Mogensen (1976) measured plasma renin activity in rats both after administration of hypertonic saline and a $24-\mathrm{h}$ period of dehydration. They reported that plasma renin activity did not increase after administration of hypertonic saline and concluded that formation of angiotensin II was not important for the induction of drinking under these conditions. However, plasma renin activity increased significantly after a $24-\mathrm{h}$ period of dehydration. The level of plasma renin activity was correlated significantly with the magnitude of the post-dehydration drinking response. The data reported in the present study, using an angiotensin converting enzyme inhibitor, agree well with those of Abdelaal, Mercer, \& Mogensen (1976).

Dual pathways for the induction of thirst and drinking have been proposed by a number of investigators (Findlay et al., 1979; Fitzsimons, 1979; Greenleaf \& Fregly, 1982; Kucharczyk \& Mogensen, 1978; Oatley, 1973). The results of the present experiments lend support to this concept. Thus, isoproterenol, angiotensin I and angiotensin II induce thirst and drinking via the angiotensin II pathway. In contrast, the drinking response to administration of hypertonic saline appears to be independent of the angiotensin II pathway and to be mediated by the osmoreceptor pathway. Dehydration-induced drinking appears to be mediated by both pathways. The redundancy in the pathways for induction of dehydration-induced drinking would appear to reflect the physiological importance of the response. Additional studies will be required to determine what proportion of the dehydration-induced drink is mediated via each pathway.

\section{REFERENCES}

Abdelaal, A. E., Mercer, P. F., \& Mogensen, G. J. Plasma angiotensin II levels and water intake following $\beta$-adrenergic stimulation, hypovolemia, cellular dehydration and water deprivation. Pharmacology, Biochemistry and Behavior, 1976, 4, 317-321.

Atkinson, J., Kaesermann, H. P., Lambelet, J., Peters, G., \& Peters-Haefeli, L. The role of circulating renin in drinking in response to isoprenaline. Journal of Physiology (London), 1979, 291, 61-73.

Barney, C. C., Katovich, M. J., \& Fregly, M. J. The effect of acute administration of an angiotensin converting enzyme inhibitor, captopril (SQ 14,225) on experimentally induced thirst in rats. Journal of Pharmacology and Experimental Therapeutics, 1980, 212, 53-57.

Blaine, E. H., Hosutt, J., Rowland, N., Stricker, E. M., \& Zimmerman, M. B. Water intake and plasma renin activity of rats after intravenous infusions of rat renin. Physiology and Behavior, 1979, 23, 605-607.

Chiaraviglio, E. Drinking behavior in rats treated with isoprenaline, angiotensin II or angiotensin antagonists. Journal of Physiology, (London), 1979, 296, 193-202.

Findlay, A. L. R., Fitzsimons, J. T., \& Kucharczyk, J. Dependence of spontaneous and angiotensin-induced drinking in the rat upon the oestrus cycle and ovarian hormones. Journal of Endocrinology, 1979, 82, 215-225.

Fitzsimons, J. T. The Physiology of Thirst and Sodium Appetite. Pp. 223-457, Cambridge: Cambridge University Press, 1979.

Fregly, M. J. Effect of chronic treatment with estrogen on the dipsogenic response of rats to angiotensin. Pharmacology, Biochemistry and Behavior, 1980,12, 131-136. 
Fregly, M.J., \& Black, B. A. Effect of methylphenidate on spontaneous activity, food intake, and cold tolerance of propylthiouracil-treated rats. Canadian Journal of Physiology and Pharmacology, 1964, 42, 415-429.

Fregly, M. J., Lockley, O. E., \& Simpson, C. E. Effect of the angiotensin-converting en $z y m e$ inhibitor, captopril, on development of renal hypertension in rats. Pharmacology, 1981, 22, $277-286$.

Goldstein, A., Biostatistics: An Introductory Text. Pp. 73 80. New York: Macmillan, 1964.

Greenleaf, J. E.. \& Fregly, M. J. Modeling Thirst. Federation Proceedings, 1982, 41, 25072508

Gross, D. M., Sweet, C. S., Ulm, E. H., Backlund, E. P., Morris, A. A., Weitz, D., Bohn, D. L., Wenger, H.C., Vassel, T. C., \& Stone, C. A. Effect of N-[(S)-1-carboxy-3-phenylpropyl]-Lala-L-pro and its ethylester (MK-421) on angiotensin converting enzyme in vitro and angiotensin I pressor response in vivo. Journal of Pharmacology and Experimental Therapeutic's, 1981, 216, 552-557.

Huntsberger, D. V. Elements of Statistical Inferences. Pp. 213-220. Boston: Allyn and Bacon, 1961 .

Katovich, M. J., Barney, C. C., Fregly, M. J., \& McCaa, R. E. Effect of an angiotensin converting enzyme inhibitor (SQ 14,225) on $\beta$-adrenergic- and angiotensin-induced thirsts. European Journal of Pharmacology, 1979,56, 123-130.

Katovich, M. J., \& Fregly, M. J. Mediation of isoproterenol-induced thirst in rats by $\beta_{2}$-adrenergic receptors. Canadian Journal of Physiology Pharmacology, 1978, 56, 465-470.

Kucharczyk, J., \& Mogensen, G. J. Specific deficits in regulatory drinking following electrolytic lesions of the lateral hypothalamus. Experimental Neurology, 1976, 53, 371-385.

Lazarow, A. Methods for quantitative measurement of water intake. Methods in Mudical Research, 1954, 6, 225-229.

Leenen, F. H., \& McDonald, R. H. The effect of isoproterenol on blood pressure, plasma renin activity and water intake in rats. European Joumal of Phamacologl, 1974, 26, 129135.

Lehr, D., Mallow, J., \& Krukowski, M. Copious drinking and simultaneous inhibition of urine flow elicited by beta-adrenergic stimulation and contrary effect of alpha-adrenergic stimulation. Journal of Phamacology Experimental Therapeutics, 1967, 158, 150-163.

Long, J. A., \& Evans, H. M. The estrous cycle in the rat and its associated phenomena. Memoirs of The University of California, 1922, 6, 1-148.

Oatley. K. Stimulation and theory of thirst. In A. N. Epstein, H. R. Kissileff, \& E. Stellar (Eds.), the Neuropsichology of Thirst: New Findings and Adrances in Concepts. Pp. 199-223. Washington: Winston, 1973.

Scammell, J. G., \& Fregly, M. J. Attenuation of isoproterenol-stimulated plasma renin activity by chronic estrogen treatment. Proceeding of the Society for Experimental Biologl and Medicine, 1981, 167, 117-121.

Snedecor, G. W. \& Cochran, W. G. Statistical Methods, 5th ed., Pp. 350-400, Ames: Iowa State College Press, 1956.

Wang, G. H. The relation between "spontaneous" activity and estrous cycle in the white rat. Comparative Psychological Monographs 1923, 2, 1-27.

Weinberger, M. H., Aoi, M. H., \& Henry, D. P. Direct effect of beta-adrenergic stimulation on renin release by the rat kidney slice in titro. Circulation Research, 1975, 37, 318--324.

Received 8 February, 1982; revision 22 June, 1982 
